Кравчина Оксана Євгенівна, молодший науковий співробітник Інформаційноаналітичного відділу педагогічних інновацій Інституту інформаційних технологій і засобів навчання Національної академії педагогічних наук України, м. Київ

\title{
АНАЛІЗ МОДЕЛЕЙ ІНФОРМАТИЗАЦІЇ ШКОЛИ В СИСТЕМАХ ОСВІТИ ЗАРУБІЖНИХ КРАЇН
}

\section{Анотація}

Інформатизація освіти є невід'ємною складовою інформатизації суспільства, відображає загальні тенденції глобалізації світових процесів розвитку, виступає як визначальний інформаційний і комунікаційний базис розвитку освіти, гармонійного розвитку особистості і соціально-економічних систем суспільства. На сьогоднішній день інформатизація освіти розвивається стихійно, іiї наслідки глибоко суперечливі, тому дана тенденція потребує осмислення, оцінки і стратегії (моделі). У статті аналізується досвід створення закордонних моделей оцінки інформатизації школи для подальшого використання цього досвіду в загальноосвітніх навчальним закладах України.

Ключові слова: інформатизація освіти, модель ЮНЕСКО, ВЕСТА Маtrix.

Bcmyn. В останні роки в багатьох країнах світового співтовариства та в Україні все більша увага приділяється проблемі інформатизації освіти, яка починає розглядатися як одна 3 найбільш важливих стратегічних проблем розвитку цивілізації. Цей процес вимагає не тільки підготовки достатньої кількості кваліфікованих фахівців, але і підвищення загального рівня комп'ютерної грамотності. Успішне вирішення цього завдання пов'язане з удосконаленням і структурною зміною системи освіти і підготовки фахівців, забезпеченням сучасного матеріально-технічного оснащення навчального процесу.

На сьогоднішній день інформатизація освіти розвивається стихійно, іiї наслідки глибоко суперечливі, тому дана тенденція потребує осмислення, оцінки і стратегії (моделі). 
Сучасні реалії інформатизації освіти в нашій країні знайшли своє відображення у роботах Л.І.Даниленко, Г.В.Сльникової, О.М.Клочко, В.І. Кудінова. Теоретичними основами використання інформаційно-комп'ютерних технологій в освіті займалися А.М.Гуржій, В.Ю.Биков, В.В.Гапон, М.Я.Плескач, Р.А.Осіпа.

За визначенням А.М.Гуржія, В.Ю.Бикова, В.В.Гапона, М.Я.Плескача інформатизація освіти - це впорядкована сукупність взаємопов'язаних організаційноправових, соціально-економічних, навчально-методичних, науково-технічних, виробничих та управлінських процесів, спрямованих на задоволення освітніх інформаційних, обчислювальних і телекомунікаційних потреб учасників навчальновиховного процесу"[4].

Метою статті є аналіз закордонних моделей оцінки інформатизації школи для подальшого використання їх в загальноосвітніх навчальним закладах України.

Отже, інформатизація освіти є невід’ємною складовою інформатизації суспільства, відображає загальні тенденції глобалізації світових процесів розвитку, виступає як визначальний інформаційний і комунікаційний базис розвитку освіти, гармонійного розвитку особистості і соціально-економічних систем суспільства.

Основними цілями інформатизації освіти є:

- підвищення ефективності управління навчальною та фінансовою діяльністю освіти;

- підвищення якості освіти за рахунок впровадження нових технологій у навчально-виховний процес;

- інтеграція системи освіти у світове співтовариство за рахунок подання актуальної і якісної інформації;

- підвищення якості надання послуг Internet, телефонії, аудіовізуального оповіщення.

Суттєвим показником розвитку освітніх установ $\epsilon$ оцінка процесу інформатизації школи. Показники технічного оснащення школи лише частково можуть свідчити про розвиток процесів інформатизації в ній. Основні показники слід істотно розширити, включивши сюди і ті, які описують:

- готовність i здатність педагогів ефективно працювати в новому інформаційному середовищі і зміна організаційних умов (педагогічна IКТкомпетентність працівників освіти); 
- зміни в методах і організаційних формах роботи учнів, окремих педагогів та педагогічного колективу школи в цілому (поширення ІКТ-підтриманих методів і організаційних форм навчання);

- зміни у змісті та очікувані результати навчання (формування у школярів уміння вчитися, готовності і здатності продуктивно працювати в колективі, вирішувати задачі, взяті з реального життя);

- зміни в управлінні навчально-виховним процесом i школою в цілому (підтримка цих процесів засобами IKT, включаючи бази даних, автоматизований облік, шкільний портал тощо),

- зміни у взаємодії з найближчим оточенням школи (батьки, спонсори, муніципальні органи влади, громадські організації).

Розроблено кілька моделей, які допомагають оцінити поточний стан інформатизації школи і планувати технологічні нововведення. Серед найбільш відомих і тих, які використовуються розробок можна виділити британську ВЕСТА Matrix [1], Модель ЮНЕСКО, а також розробка російських вчених «Московська таблиця» .

Перша - Модель ЮНЕСКО є досить типовим якісним описом процесу інформатизації. Однією з традиційних складових процесу інформатизації школи $\epsilon$ підготовка учнів і педагогів в області ІКТ. Колектив авторів під егідою ЮНЕСКО [2], узагальнивши досвід різних країн, розробив типові плани такої підготовки i запропонував чотирьохетапну нормативну модель освоєння IКТ в рамках школи. У моделі виділено чотири підходи до процесу інформатизації школи, а саме:

- зародження;

- впровадження;

- поширення;

- трансформація.

Зародження характерне для шкіл, які приступають до освоєння ІКТ. В таких школах немає продуманої програми інформатизації. Ця ситуація притаманна для наших сільських шкіл, в яких модель навчання, що діє, не змінюється.

Впровадження характерне для шкіл, в яких адміністрація та педагоги розуміють важливість ІКТ для вирішення завдань освітньої підготовки школярів. У таких школах вчителі і адміністратори застосовують комп'ютери при вирішенні 
завдань, що традиційно стоять перед ними. Вони використовують ІКТ для підготовки документів, роздаткових матеріалів і презентацій. Школярі освоюють комп'ютер в рамках спеціальних учбових занять. В той же час традиційна організація навчального процесу залишається практично незмінною.

Поширення характерне для шкіл, де адміністрація та педагоги виявляють шляхи підвищення ефективності своєї роботи за рахунок використання IКТ. У цих школах починається інтеграція навчальних дисциплін. Перед учнями ставляться завдання, які вимагають від них застосовувати отримані знання в реальних умовах. Матеріали для навчання беруться не лише з підручників і хрестоматій, але і з інших джерел, включаючи засоби масової інформації та Інтернет. Школярі використовують засоби IKT, які полегшують їх навчання, допомагають продемонструвати повноцінність і практичне застосування набутих знань. Гнучка організація учбового процесу дозволяє повніше враховувати індивідуальні особливості школярів, їх інтереси та методи навчання.

Учні беруть на себе відповідальність за хід і результати навчання та оцінки. Школа залучає до своєї роботи місцеве співтовариство, перетворюючи оточення в складову частину освітнього середовища.

Трансформація характерна для шкіл, де творчо використовують IКТ для переосмислення (трансформації) навчально-виховного середовища. Використання ІКТ стає повсякденною справою, що підвищує ефективність роботи всіх членів освітнього співтовариства. Акцентується увага на індивідуальній роботі, школярі вирішують практичні завдання, використовуючи матеріали різних навчальних предметів і засобів ІКТ. Школа стає культурним і освітнім центром місцевого співтовариства.

Кожен з перерахованих етапів процесу інформатизації школи можна описати за допомогою окремих характеристик їі роботи. У Моделі ЮНЕСКО виділяється вісім таких характеристик:

- ініціатори;

- освітня концепція;

- планування;

- техніка і ресурси;

- місце в навчальному плані; 
- ІКТ-підготовка працівників школи;

- зв'язок з громадськістю;

- оцінка.

Ініціатори - опис формування уявлень про бажане майбутнє і цілей як окремих педагогів, так і школи в цілому. В залежності від розвитку процесу інформатизації місія школи в області ІКТ формулюється все більш виразно. Це допомагає членам педагогічного колективу представити образ бажаного майбутнього для своєї школи і створює основу для ухвалення відповідних управлінських рішень.

Освітня концепція - фіксуються способи організації освітнього процесу, типові взаємодії між учнями і педагогами, що в значній мірі зумовлює процес впровадження IКТ. При традиційному дидактичному підході вчитель вважає себе основним носієм знань в своій області. Його завдання - донести ці знання до учнів використовуючи для цього ІКТ. Навпаки, освітня концепція, орієнтована в першу чергу на потреби учнів, коли знання поступають до нього з багатьох джерел. При такому підході IКТ і цифрові освітні ресурси розглядаються перш за все як інструмент навчання школярів.

Планування - дозволяє перетворювати загальні уявлення про бажане майбутнє і цілі в практичні плани інформатизації школи відповідно до прийнятої освітньої концепції.

Техніки i ресурси описують умови використання IКТ для формування навчального середовища в школі. До техніки відносяться: електропостачання, меблі, канали зв'язку для доступу до Інтернету тощо. Недостатньо ергономічні меблі, наприклад, можуть не лише знизити ефективність використання IКT, але й нанести шкоду здоров'ю учнів. До ресурсів відносяться всі технологічні пристрої (системні блоки, монітори, периферійні пристрої і тому подібне), а також програмні засоби, цифрові освітні ресурси, аудіо і відеозаписи, різна документація (включаючи паперові довідники, технічне керівництво тощо).

Місце в навчальному плані показує, наскільки інтенсивно ІКТ включені до систематичного навчання. Залежно від прийнятого школою підходу до процесу інформатизації місце ІКТ в навчальному плані може істотно мінятися.

ІКТ-підготовка працівників школи розглядає зміни у процесі професійної підготовки педагогів. Ці зміни включають початкове знайомства з IКТ, формування технологічної грамотності та педагогічної IКТ- компетентності педагогів, а також 
освоєння нових педагогічних технологій, які безпосередньо не пов'язані з IКТ, але стали можливими при умові ІКТ-насиченого освітнього середовища.

Зв'язок з громадськістю - описується залучення місцевого співтовариства в роботу школи. На початкових етапах (Зародження і Впровадження) зв'язок школи i співтовариства традиційні: школа шукає допомоги для покупки нової техніки та іiі ремонту. На наступних етапах (Поширення і Трансформація) освітнє середовище все більше виходить за межі шкільної будівлі. Школа залучає до своєї роботи не лише окремих батьків, але і все місцеве співтовариство (підприємства, культурні і релігійні організації тощо) та перетворюється на один з центрів суспільного життя.

Оцінка - змінюється оцінювання роботи школи та оцінка навчання учнів. При оцінці досягнень учнів в процесі інформатизації школи змінюється не лише інструменти, але і методи оцінки. Наприклад робота з олівцем і папером замінюється на роботу з комп'ютером. Вчителі переходять від констатуючого оцінювання до того, що формує, від формальних методів (тести успішності) до автентичних (оцінювання результатів проектної роботи учнів, формування портфоліо). Оцінка, що виставляється вчителем, все більш змінюється на самооцінку та оцінку, яку дають учневі інші члени навчального співтовариства.

У табл. 1 [2] приведені індикатори стану процесу інформатизації школи (Модель ЮНЕСКО). Модель є матрицею, стовпці якої відповідають етапам процесу інформатизації школи, а рядки - характеристикам їі роботи. Кожен елемент матриці містить індикатори, які дозволяють оцінити характеристики школи, що знаходиться на тому або іншому етапі інформатизації.

Таблиця 1. Індикатори стану процесу інформатизації школи

\begin{tabular}{|c|c|c|}
\hline Зародження & Впровадження & Поширення \\
\hline \multicolumn{3}{|l|}{ Iніüіатори } \\
\hline $\begin{array}{l}\text { Окремі ентузіасти які } \\
\text { використовують ІКТ для } \\
\text { вирішення приватних } \\
\text { завдань. }\end{array}$ & $\begin{array}{l}\text { Викладачі } \\
\text { інформатики і окремі } \\
\text { ентузіасти. }\end{array}$ & $\begin{array}{l}\text { Багато вчителів- } \\
\text { предметників, } \\
\text { використовують ІКТ для } \\
\text { своїх занять за підтримки } \\
\text { адміністрації. }\end{array}$ \\
\hline \multicolumn{3}{|l|}{ Освітня концеепція } \\
\hline $\begin{array}{l}\text { Домінує традиційний } \\
\text { дидактичний підхід. }\end{array}$ & $\begin{array}{l}\text { Домінує традиційний } \\
\text { дидактичний підхід. } \\
\text { Інформатика вивчається як } \\
\text { окремий предмет }\end{array}$ & $\begin{array}{l}\text { Традиційний дидактичний } \\
\text { підхід перестає домінувати. } \\
\text { Виникає орієнтація на } \\
\text { потреби учнів, групову } \\
\text { роботу і співпрацю. }\end{array}$ \\
\hline
\end{tabular}




\begin{tabular}{|c|c|c|c|}
\hline & & & \\
\hline \multicolumn{3}{|l|}{ Планування } & \\
\hline $\begin{array}{l}\text { Відсутнє або носить } \\
\text { фрагментарний характер. } \\
\text { Витрати на IКТ не } \\
\text { плануються. }\end{array}$ & $\begin{array}{l}\text { Носить обмежений } \\
\text { характер. Їм займаються } \\
\text { фахівці з ІКТ. Рішення } \\
\text { приймаються } \\
\text { централізовано, їх мета - } \\
\text { поставка технічних і } \\
\text { програмних засобів. } \\
\text { Автоматизується існуюча } \\
\text { практика. }\end{array}$ & $\begin{array}{l}\text { Орієнтовано на використання } \\
\text { ІКТ для розвитку окремих } \\
\text { навчальних предметів. } \\
\text { Використовується підхід } \\
\text { «Вирішується». Бюджет всіх } \\
\text { заходів включає підготовку } \\
\text { вчителів-предметників. }\end{array}$ & \\
\hline \multicolumn{3}{|l|}{ Техніки і ресурси } & \\
\hline $\begin{array}{l}\text { Типове робоче місце: } \\
\text { комп'ютер і принтер. } \\
\text { Оснащені окремі робочі } \\
\text { місця у адміністраторів і в } \\
\text { окремих класах. } \\
\text { Використовуються ігри і } \\
\text { офісні пакети (текстовий } \\
\text { процесор, електронні } \\
\text { таблиці, презентаційна } \\
\text { графіка, бази даних). }\end{array}$ & $\begin{array}{l}\text { Комп'ютерні класи } \\
\text { (лабораторії) для навчання } \\
\text { інформатиці. Окрім } \\
\text { комп'ютерів і принтерів, є } \\
\text { і інша периферія. } \\
\text { Обмежений доступ до } \\
\text { Інтернету. } \\
\text { Використовуються офісні } \\
\text { пакети і програмні засоби } \\
\text { для навчання ІКТ. }\end{array}$ & $\begin{array}{l}\text { Комп'ютерні лабораторії і } \\
\text { комп'ютери в класах. } \\
\text { Об'єднання комп'ютерів в } \\
\text { мережу (Інтранет). } \\
\text { Використання Інтернету. } \\
\text { Насичені ресурсами учбові } \\
\text { центри. Розвинена периферія, } \\
\text { яка включає цифрові камери, } \\
\text { сканери, відео і аудіо } \\
\text { магнітофони, портативні } \\
\text { комп'ютери, датчики для } \\
\text { комп'ютерних лабораторій. } \\
\text { Засоби для відео } \\
\text { конференцій. Офісні і наочно- } \\
\text { орієнтовані програмні засоби. } \\
\text { Цифрові навчальні матеріали } \\
\text { за окремими предметами. } \\
\text { Авторські засоби для } \\
\text { створення відео, аудіо і } \\
\text { мультимедіаматеріалів. }\end{array}$ & \\
\hline \multicolumn{3}{|c|}{ Місие в навчальному плані } & \\
\hline $\begin{array}{l}\text { Оволодіння ІКТ - } \\
\text { грамотністю й знайомство } 3 \\
\text { програмним забезпеченням } \\
\text { залежить від бажання } \\
\text { вчителів. }\end{array}$ & $\begin{array}{l}\text { ІКТ застосовуються на } \\
\text { окремих навчальних } \\
\text { предметах. } \\
\text { Використовуються } \\
\text { ізольовані ЦОР, можливі } \\
\text { лише в навчальній } \\
\text { ситуації завдання. }\end{array}$ & $\begin{array}{l}\text { Освоєння ІКТ пов'язане з } \\
\text { вивченням різних навчальних } \\
\text { предметів. Для підтримки } \\
\text { навчання використовуються } \\
\text { віртуальні освітні } \\
\text { середовища, матеріали з } \\
\text { реального життя (практичне } \\
\text { навчання), навчальні освітні } \\
\text { проекти, пов'язані з } \\
\text { вирішенням конкретних } \\
\text { проблем. Все навчання } \\
\text { відбувається в ІКТ - } \\
\text { насиченому навчальному } \\
\text { середовищі. }\end{array}$ & \\
\hline
\end{tabular}




\begin{tabular}{|c|c|c|}
\hline \multicolumn{3}{|c|}{ ІКТ підготовка працівників школи } \\
\hline $\begin{array}{l}\text { Підготовка на основі } \\
\text { особистої зацікавленості. }\end{array}$ & $\begin{array}{l}\text { Разові заходи щодо } \\
\text { навчання працівників } \\
\text { школи комп'ютерної } \\
\text { грамотності. }\end{array}$ & $\begin{array}{l}\text { Формування професійних } \\
\text { навиків з орієнтацією на } \\
\text { навчальні дисципліни та їх } \\
\text { інтеграцію на основі } \\
\text { використання ІКТ. }\end{array}$ \\
\hline \multicolumn{3}{|c|}{ Зв'язок з громадськістю } \\
\hline $\begin{array}{l}\text { Випадковий, у міру } \\
\text { виникнення проблем. } \\
\text { Постачання засобів IКТ } \\
\text { (окремі пожертвування). }\end{array}$ & $\begin{array}{l}\text { Пошук грантів і дарунків } \\
\text { на розвиток ІКТ в школі. } \\
\text { Залучення до цієї роботи } \\
\text { батьків. }\end{array}$ & $\begin{array}{l}\text { Епізодична взаємодопомога } \\
\text { (за запитом) надають наочно- } \\
\text { орієнтовані освітні } \\
\text { співтовариства. Спілкування } \\
\text { за допомогою Інтранету і } \\
\text { Інтернету. }\end{array}$ \\
\hline \multicolumn{3}{|l|}{ Оцінкка } \\
\hline $\begin{array}{l}\text { Акцент на наявність техніки } \\
\text { і на виконання бюджету. } \\
\text { Контролююча оцінка знань, } \\
\text { умінь і навиків школярів } \\
\text { проводиться в рамках } \\
\text { окремих предметів } \\
\text { вчителями-предметниками. } \\
\text { При оцінці } \\
\text { використовуються олівець і } \\
\text { папір. }\end{array}$ & $\begin{array}{l}\text { Контролююча оцінка } \\
\text { знань, умінь і навиків } \\
\text { школярів проводиться в } \\
\text { рамках окремих предметів } \\
\text { вчителями- } \\
\text { предметниками. При } \\
\text { оцінці використовуються, } \\
\text { у тому числі, засоби } \\
\text { автоматизованого } \\
\text { контролю. }\end{array}$ & $\begin{array}{l}\text { Інтегрована оцінка досягнень } \\
\text { школярів носить формуючий } \\
\text { характер (містить } \\
\text { рекомендації для подальшої } \\
\text { роботи) і включає результати } \\
\text { навчання і виховання. При } \\
\text { оцінці, разом з іншими } \\
\text { засобами, використовуються } \\
\text { засоби мультимедіа для } \\
\text { демонстрації досягнень і } \\
\text { портфоліо. Процес оцінки } \\
\text { заснований на } \\
\text { відповідальності учнів. }\end{array}$ \\
\hline
\end{tabular}

Модель ЮНЕСКО пропонує працівникам школи інструмент для якісного оцінювання стану, в якому знаходиться школа. Модель можна з успіхом використовувати для самооцінки. Автори моделі відзначають [3], що працівники школи можуть віднести себе до одного або до декількох елементів в кожному рядку матриці. Хоча віднесення школи до певного етапу $\epsilon$ приблизним, воно може допомогти педагогам у визначенні орієнтирів, а також в уточненні розробленої експертами ЮНЕСКО програми підвищення кваліфікації педагогів.

Друга, Модель ВЕСТА [1] - один 3 сучасних інструментів для оцінки і планування процесу інформатизації школи, де інформатизація школи розглядається 
як процес переходу від нижніх до більш високих рівнів по кожному з 32-х виділених авторами моделі аспектів. Перелік цих аспектів наведено в табл. 2.

Для кожного аспекту Матриця ВЕСТА задає шість рівнів розвитку:

1. Процес не організований, і використання IКТ ніяк не регламентується.

2. Процес пов'язаний з окремими сторонами роботи школи і в цілому не координується. ІКТ використовують за особистою ініціативою.

3. Процес використання IКТ координується в рамках школи, створений або вже почав діяти механізм підтримки та координації робіт.

4. Процес розвивається, для його підтримки систематично прикладаються спеціальні зусилля. Засоби ІКТ використовуються регулярно, хоча, можливо, і не всіма працівниками освітньої установи.

5. Процес вийшов на новий якісний рівень. Засоби IКТ органічно вбудовані в роботу школи. Їх використання стало нормою, повсякденним елементом освітньої роботи всіх освітян та учнів.

6. Використання засобів IКТ перетворює роботу школи, вони широко застосовуються в організованому по-новому навчально-виховному процесі. Учні отримують нові види освітніх послуг, мета яких - досягнення нової якості освіти. Вирішуються нетрадиційні для школи освітні завдання.

Таким чином, вибудовується багатовимірна оцінка рівня інформатизації школи. Табл. 2. Області та аспекти Матриці ВЕСТА

\begin{tabular}{|c|c|c|}
\hline № & Область & Аспект \\
\hline 1. & $\begin{array}{lr}\text { Формування } & \text { образу } \\
\text { бажаного майбутнього i } \\
\text { планування } \\
\text { досягнення }\end{array}$ & $\begin{array}{l}\text { 1.1. Програма розвитку школи } \\
\text { 1.2. Трирічний план розвитку школи } \\
\text { 1.3. Керування програмою розвитку школи } \\
\text { 1.4. Управління розвитком технологій навчання } \\
\text { 1.5. Програма розвитку e-learning } \\
\text { 1.6. Фінансування } \\
\text { 1.7. Розробка моделей для e-learning } \\
\text { 1.8 Зовнішні зв'язки школи }\end{array}$ \\
\hline 2. & Процеси навчання & $\begin{array}{l}\text { 2.1. Опора навчальної програми школи на нові педагог) } \\
\text { 2.2. Автоматизація управління освітніми ресурсами } \\
\text { 2.3. Організація ресурсів, які доступні в режимі on-line } \\
\text { 2.4. Розвиток комунікацій } \\
\text { 2.5. Розвиток зовнішнього доступу } \\
\text { 2.6. Навчальні стилі } \\
\text { 2.7. Розвиток учнів } \\
\text { 2.8. Навики виконання роботи з використання Інтернет }\end{array}$ \\
\hline
\end{tabular}




\begin{tabular}{|c|c|c|}
\hline 3. & $\begin{array}{l}\text { Підвищення } \\
\text { персоналу }\end{array}$ & $\begin{array}{l}\text { 3.1. Освоєння аналізу потреб (needs analysis) } \\
\text { 3.2. Використання e-learning } \\
\text { 3.3. Розуміння е-learning } \\
\text { 3.4. Програми підвищення кваліфікації персоналу }\end{array}$ \\
\hline 4. & $\begin{array}{l}\text { Управління школою та } \\
\text { розвиток } \\
\text { автоматизованої } \\
\text { інформаційно-керуючої } \\
\text { системи (АСУ) }\end{array}$ & $\begin{array}{l}\text { 4.1. Ведення звітності } \\
\text { 4.2. Проспекти } \\
\text { 4.3. Реєстрація } \\
\text { 4.4. Відвідуваність } \\
\text { 4.5. Облік навчальної роботи школярів і підготовка зві7 } \\
\text { 4.6. Підготовка довідок } \\
\text { 4.7. Розклад занять і використання приміщень } \\
\text { 4.8. Інтеграція адміністративних даних з даними про на }\end{array}$ \\
\hline 5. & $\begin{array}{l}\text { Управління } \\
\text { ІКТ-ресурсами }\end{array}$ & $\begin{array}{l}\text { 5.1. Технічна підтримка } \\
\text { 5.2. Технічні засоби } \\
\text { 5.3. Підключення до Інтернет } \\
\text { 5.4. Розвиток шкільної комп'ютерної мережі (Інтра } \\
\text { платформи }\end{array}$ \\
\hline
\end{tabular}

Запропонована система оцінок дозволяє порівнювати школи з різних аспектів, i навіть служить підставою для їх сертифікації. Використовуючи ці оцінки, Британське Міністерство освіти працює над єдиною процедурою для сертифікації шкіл в області інформатизації. Багатомірна оцінка дозволяє не тільки зафіксувати досягнення шкіл але i допомагає зробити цей процес максимально прогнозованим i керованим. Останнє пов'язане з тим, що інформатизація розглядається не як окремий акт, а як процес розвитку освітньої установи, який проходить багато окремих стадій. Розробники Матриці ВЕСТА розмістили опитувальник безпосередньо на сайті. Після заповнення кожного розділу форми, працівникам школи пропонується визначити, що треба зробити, щоб підвищити рівень їі інформатизації і поліпшити роботу щодо аспектів, що відносяться до даного розділу. Таким чином, Матриця ВЕСТА допомагає не тільки оцінити стан інформатизації школи, а й розробити план дій для вдосконалення роботи з окремих напрямів, познайомитися з рекомендаціями про те, як зробити наступний крок розвитку, отримують посилання на досвід інших шкіл, де це завдання вже вирішено. Сьогодні Матриця ВЕСТА являє собою корисний інструмент, яким кожен може скористатися за допомогою Інтернету.

Московська таблиця [5] - це система таблиць, яка допомагає планувати та оцінювати процес реалізації програм інформатизації школи, а також дозволяє колективу школи вести моніторинг створення єдиного інформаційного простору своєї освітньої установи. 
В основі підходу, що розвивається авторами, лежить уявлення про те, що інформаційне середовище школи це не лише встановлені в школі комп'ютери і уроки інформатики, а й саме застосування IКТ в освітньому процесі. Мета даної розробки - інтенсифікувати застосування IКТ в рамках окремих навчальних предметів, збільшити час з їх використання на уроках і в позаурочний час до 12 годин щоденно протягом всього тижня. В зв'язку з цим органам освіти пропонується забезпечити:

- створення і розвиток шкільних медіатек;

- доступ учнів і вчителів до освітніх ресурсів в Інтернеті;

- функціонування АIC освітніх установ;

- інформаційна взаємодія (електронна пошта, веб-сайти) з іншими школами, органами місцевого самоврядування, громадськістю.

У позаурочний час в школах рекомендується організувати:

- проведення і консультації з навчання і проектної діяльності учнів по різним предметам, пов'язаними, зокрема, із застосуванням ІКТ (пошук інформації, оформлення навчальних робіт тощо);

- доступ до засобів IКT та інших ресурсів, надання допомоги 3 їх використання учням і вчителям (пізнавальна і розвиваюча діяльність учнів, розробка методик уроків, підготовка методичних матеріалів, наукових розробок, звітної і діагностичної документації, матеріалів для учбових i суспільних заходів тощо);

- позаурочну діяльність із застосуванням IКТ (наочні лабораторії, конкурси і олімпіади, інші форми виховної роботи і діяльності з соціалізації підлітків);

- роботу шкільних засобів масової інформації 3 використанням ІКТ (оновлення веб-сторінок в Інтернеті, газети, журнали, шкільне TV, оформлення кабінетів);

- дозвілля дітей в шкільному комп'ютерному клубі (наприклад, клуб програмістів, Інтернет-клуб, комп'ютер для молодших школярів, клуб комп'ютерних презентацій, комп'ютерний шаховий клуб тощо).

Автори розробили систему оцінок (таблиць), що фіксують зміни в житті школи як результат освоєння i використання засобів IКТ навчального призначення (комп'ютеризовані лабораторії, електронні мікроскопи, мультимедіапроектори і тому подібне). Всі засоби підтримують специфічні моделі використання комп'ютерів в 
школі, а їх постачання супроводжується заходами щодо підготовки вчителів. Автори виділяють дев'ять специфічних «видів діяльності» або «різних моделей і сценаріїв навчальної діяльності» [5]:

- пошук інформації (включає уміння формулювати питання і користуватися пошуковими системами);

- комп'ютерний збір і аналіз інформації про навколишній світ (включає записи спостережень в текстовій формі, фотографії, аудіо і відеозаписи);

- створення гіпермедіатворів (включає твори, що створюються дітьми в рамках художньої праці і образотворчого мистецтва, а саме тексти, малюнки, звукові фрагменти, комп'ютерну мультиплікацію, редагують їх і організовують в зв'язну структуру);

- створення веб-сторінок;

- підготовка i проведення мультимедіавиступів (поєднання традиційного виступу з мультимедійною презентацією);

- комп'ютерне тестування (використовується при оцінці результатів навчання учнів);

- проектування і конструювання (використовуються на всіх етапах роботи: при формуванні цілей проекту, при описі ресурсів i обмежень, при створенні віртуальних моделей, при реалізації проекту і пред'явленні результатів);

- занурення в мовне середовище (використовуються інтерактивні програми, тексти, відеофрагменти, аудіозаписи тощо);

- відтворення технічних навиків (включає освоєння роботи 3 клавіатурою, тренажери для вироблення навиків управління різними технічними пристроями, такими як: літальні апарати, автотранспортні засоби та ін.).

Рівень інформатизації школи оцінюється за допомогою дев'яти таблиць, які фіксують:

- забезпечення засобами IКT;

- забезпечення кадрами;

- напрями і доступність використання засобів IКТ (комп'ютеризовані робочі місця); 
- використання IКТ в навчальному процесі початкової, основної і старшої школи, а також в школі в цілому;

- створення єдиного інформаційного простору школи;

- використання цифрових і освітніх ресурсів.

Як приклад приведено форму в табл. 3, яка фіксує використання IКТ в навчальному процесі старшої школи з двох предметів.

Табл. 3. Використання ІКТ в навчальному процесі старшої школи

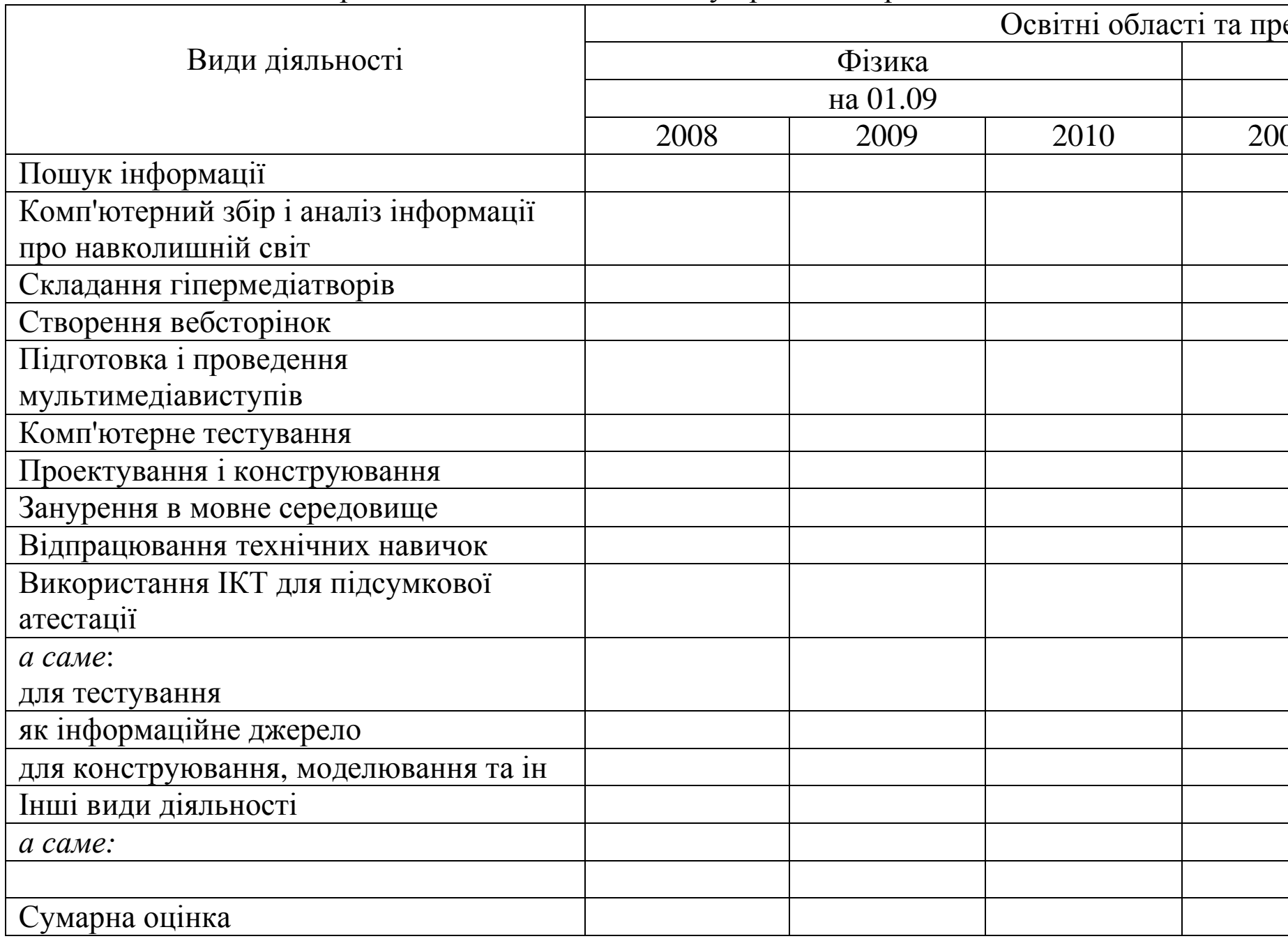

Запропонований московськими розробниками підхід добре зарекомендував себе в умовах Москви, де в школах централізовано поставляється набір широко тиражованих моделей використання IКТ в навчальному процесі. В той же час даний підхід недостатньо враховує ініціативні дії окремих вчителів i педагогічних колективів, коли ці дії виходять за рамки централізовано підтриманих моделей. Крім того, даний підхід малопридатний, якщо перелік моделей використання ІКТ в навчальному процесі не фіксується. 
У практиці роботи вітчизняної школи при описі станів інформатизації шкіл доводиться користуватися критеріями, які більш доступні для оцінки i, так чи інакше, відображають процеси інформатизації школи, а саме три групи критеріїв, які характеризують:

- технологічні аспекти процесу інформатизації школи (включаючи цифрові освітні ресурси),

- компетентність учасників освітнього процесу в області використання IKT,

- організаційні умови і доступність засобів ІКТ в школі.

Ці критерії сьогодні використовуються для оцінки розвитку процесів інформатизації школи. Взяті в сукупності, ці показники визначають стан процесу інформатизації в освітній установі.

Інтегрована зовнішня оцінка результатів виконання програм інформатизації освітніх установ (моніторинг розвитку процесів інформатизації шкіл у регіоні) може розглядатися як природне продовження роботи 3 підготовки цих програм. Для проведення зовнішнього оцінювання необхідні відомості по трьох напрямах роботи школи:

- ситуація, яка була на момент розробки програми інформатизації

- бажане або те що заплановане на кінець програми

- кінцевий результат, на момент завершення програми.

Висновок. В статті розглянуто декілька широко відомих описів (моделей) процесу інформатизації школи, які, так або інакше, використовуються на практиці. Модель ЮНЕСКО надає досить загальний якісний опис процесів удосконалення роботи школи. Ї̈ї призначення - допомогти педагогам обговорювати загальну картину процесів, які спостерігаються в системі освіти. Дві інші (Московська таблиця і Матриця ВЕСТА) розроблялися безпосередньо для вирішення завдань управління школою. Кожна 3 них орієнтована на свої специфічні умови застосування. Московська таблиця служить інструментом проведення в життя єдиної політики впровадження в школи педагогічно оформлених засобів IКТ. Друга модель намагається виділити рівні руху школи на шляху до ідеалу. Ідеї, які були використані при побудові Матриці ВЕСТА, досить популярні серед педагогів різних країн, які створюють на цій базі власні розробки. 
На жаль, можливості застосування цього інструменту в нашій країні обмежені. I справа не тільки в тому, що рівень доступу до IКТ в українських школах помітно нижче, ніж у школах Англії, а в тому що Матриця ВЕСТА орієнтована на якісно іншу організаційну культуру роботи школи. Досить зауважити, що чверть всіх аспектів, за якими оцінюється рівень інформатизації школи, пов'язані з формуванням образу бажаного майбутнього і плануванням його досягнення. У наших школах подібна практика просто відсутня.

\section{Список використаних джерел}

1. Developing an e-learning strategy: BECTRA Matrix - [Електронний ресурс]. Режим доступу: http://designing.flexiblelearning.net.au/tours/documents/becta matrix.pdf - Заголовок з екрану.

2. Information and Communication Technology in Education: A Curriculum for Schools and Programme of Teacher Development. UNESCO - [Електронний ресурс]. Режим доступу: $\quad$ http://www.ifip-tc3.net/article.php3?id_article=124 - Заголовок 3 екрану.

3. Life at Work in the Information Economy. World Employment Report [Електронний ресурс]. - Режим доступу: http://www.ilo.org - Заголовок з екрану.

4. Гуржій А.М., Биков В.Ю., Гапон В.В., Плескач М.Я. Аналіз стану комп'ютеризації загальноосвітніх навчальних закладів за 1997-2001 роки //Комп'ютер у школі та сім'ї. - 2002. - № 4. - С.3.

5. Программа развития информационной среды общеобразовательного учреждения. Проектирование и реализация / Под ред. А.Л. Семенова, Е.И. БулинСоколовой. - М.: ЦИТУО. - 2003.

\section{АНАЛИЗ МОДЕЛЕЙ ИНФОРМАТИЗАЦИИ ШКОЛЫ В СИСТЕМАХ ОБРАЗОВАНИЯ ЗАРУБЕЖНЫХ СТРАН}

Кравчина О. $E$.

\section{Аннотация}

Информатизация образования является неотъемлемой составляющей информатизации общества, отражает общие тенденции глобализации мировых процессов развития, выступает как определяющий информационный и коммуникационный базис развития образования, гармоничного развития личности и социально-экономических систем общества. На сегодняшний день информатизация 
образования развивается стихийно, ее последствия глубоко противоречивы, поэтому данная тенденция требует осмысления, оценки и стратегии (модели). В статье анализируется опыт создания иностранных моделей оценки информатизации школы, для дальнейшего использования этого опыта в общеобразовательных учебных заведениях Украины.

Ключевые слова: информатизация образования, модель ЮНЕСКО, ВЕСТА Matrix.

\title{
ANALYSIS OF SCHOOL INFORMATIZATION MODELS IN THE SYSTEMS OF EDUCATION IN FOREIGN COUNTRIES
}

Kravchina $O$. E.

\begin{abstract}
Resume
Informatization of education is an integral part of society informatization, it reflects general trends of globalization development processes in the world, existing as the determining basis of information and communication development of education, the harmonious development of personality and socio-economic systems of society. Today, informatization of education is developing spontaneously, its consequences are deeply controversial, so this trend demands the understanding, assessment and strategy (model). The article analyzes the experience of foreign models creation of school informatization assessment for use of this experience later in secondary education in Ukraine.
\end{abstract}

Keywords: informatization of education, UNESCO model, BECTA Matrix. 